\title{
Toll-Like Receptor 2
}

National Cancer Institute

\section{Source}

National Cancer Institute. Toll-Like Receptor 2. NCI Thesaurus. Code C30102.

Toll-like receptor 2 (784 aa, $\sim 90 \mathrm{kDa}$ ) is encoded by the human TLR2 gene. This protein is involved in signal transduction that modulates innate immunity. 